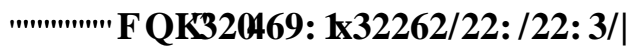

\title{
NEW TECHNOLOGIES FOR AIR TRAFFIC SECURITY
}

\section{NOWE TECHNOLOGIE DLA BEZPIECZEŃSTWA RUCHU LOTNICZEGO}

\author{
Leszek Loroch', Andrzej Żyluk ${ }^{2}$ \\ $(1,2)$ Air Force Institute of Technology \\ Instytut Techniczny Wojsk Lotniczych \\ 01-494 Warsaw ul. Księcia Bolesława 6
}

e-mails: (1) leszek.loroch@itwl.pl, (2) andrzej.zyluk@,itwl.pl

\begin{abstract}
Security of increasing intensity of air traffic requires significant technological support. In Europe, the dynamics of this phenomenon will be additionally stimulated by implementation of unmanned aerial vehicles (UAVs) into the air traffic. For effective operation of aircraft fleet it is necessary to employ new on-board diagnostic devices and flight recorders in order to evaluate technical condition of aircraft's instrumentation. Reducing the pilots' workload requires the development of new integrated digital avionics. On the other hand, in order to make the air traffic more secure, it is necessary to develop "sense and avoid" systems not only for UAVs, but for piloted aircraft, as well. On-ground support requires the effective airport/airfield protection and keeping airfield pavements well-maintained and safe.
\end{abstract}

Keywords: security of air traffic, unmanned aerial vehicles (UAVs), integrated digital avionics, airport protection

Streszczenie: W narastającym ruchu lotniczym zachowanie bezpieczeństwa tego ruchu wymaga istotnego wsparcia ze strony nowych technologii. Dynamika wzrostu ruchu lotniczego w Europie będzie narastać, z uwagi na konieczność wprowadzenia do przestrzeni powietrznej bezpilotowych statków powietrznych (BSP). Efektywne wykorzystanie posiadanej floty statków powietrznych (SP) wymusza wprowadzenie na pokłady SP nowych urządzeń diagnostycznych, rejestrujących przebieg lotu również pod kątem stanu technicznego urządzeń pokładowych. Zmniejszenie obciążenia pracą pilotów liniowych wymusza, z kolei, opracowanie wyposażenia awionicznego w zintegrowanej technice cyfrowej, a zapewnienie bezpieczeństwa ruchu - opracowania systemów „sense and avoid”, nie tylko dla BSP. W części ,naziemnej” wsparcia technicznego, ważne jest zapewnienie odpowiedniego stanu technicznego nawierzchni lotniskowych oraz ochrony lotniska jako całości.

Słowa kluczowe: bezpieczeństwo ruchu lotniczego, bezpilotowe statki powietrzne (BSP), zintegrowana awionika cyfrowa, ochrona lotniska 


\section{NEW TECHNOLOGIES FOR AIR TRAFFIC SECURITY}

\section{Introduction}

Heavy air traffic intensity in global dimension is particularly concerns the regions of North America, South-East Asia and Europe. Location of Poland in Central Europe causes that the estimated increase of civilian air traffic in the Middle Europe countries will be at the level of $15-16 \%$ [8] in the nearest years and taking into account the current increase in Poland at the level of $20 \%$. Keeping the accident coefficient (quantity of accidents for one million of check-in passengers) at the present level is an insufficient activity but the tendency of decreasing of the accident coefficient is not guaranteed. The effectiveness of security processes which is measured in the abovementioned way has got admittedly decreasing trend but in the years $1992-$ 2006 no large progress was achieved and the number of fatalities resulting from air crashes in Europe is proportional to the air traffic. Factors influencing such a state of affairs can include: significant traffic intensity, air traffic management system not partly correspondent to the air traffic intensity, severe competition on the air service market that leads to excessive equipment operation, training problems, particularly important for crews of aircrafts. A positive fact in this subject can be the introduction of new aircraft types of a high security flight level (air traffic) achieved on the basis of the most up-to-date technologies. The formulated requirements for the air traffic management system (ATM) foresee that up to the year 2015 the number of crashes caused by management errors should be reduced by about $2 / 3$. This indicates the necessity of development and implementation of a new air traffic management system.

New technologies used on boards of line passenger aircrafts but also technologies worked out for general aviation (general aviation [GA]) and air force active in great part from civilian airports can constitute technical support in the field of air traffic security.

The list of air events of Polish passenger aviation up to 31.12.2006 is given in table 1. The main influence on the deterioration of air traffic in 2006 was insufficient training of private aircraft pilots including in principle ultralights, worsening of technical service level and in communication aviation increasing of dangerous closeness between aircrafts. 
Nowe technologie dla bezpieczeństwa ruchu lotniczego

Table 1

\begin{tabular}{|c|c|c|c|c|c|}
\hline \multirow{2}{*}{ Year } & \multirow{2}{*}{$\begin{array}{c}\text { Number of } \\
\text { events }\end{array}$} & \multicolumn{4}{|c|}{ including } \\
\cline { 3 - 6 } & & crashes & $\begin{array}{l}\text { fatal } \\
\text { accidents }\end{array}$ & $\begin{array}{c}\text { serious } \\
\text { incidents }\end{array}$ & incidents \\
\hline 2006 & 378 & 100 & 16 & 16 & 268 \\
\hline 2005 & 297 & 75 & 10 & 37 & 185 \\
\hline 2004 & 314 & 98 & 16 & 15 & 201 \\
\hline 2003 & 203 & 97 & 14 & 2 & 108 \\
\hline
\end{tabular}

During last years technologies ensuring effective protection of airport infrastructure especially exposed to terrorist attacks became important. Key technologies for safety systems are included in the European Union priorities.

\section{Unmanned aircrafts vs. air traffic safety.}

Usage of unmanned air vehicles (UAV) in the open air space brings about the necessity of solving many problems and issues that will make possible the operational usage of UAV and at the same time their further development. These problems defined by JAA and EUROCONTROL found their place in studio work organized by the European Defense Agency named „Technology Demonstration Study on Sense Avoid Technologies for Long Endurance Unmanned Air Vehicles" [1]. The studio purpose was to define technical solutions in the range of "Sense and Avoid" technology for UAV (unnamed air vehicles) in the purpose of their integration with civilian air traffic and making their usage in critical management operations possible .

Collision avoiding is determined on two levels : the first is to ensure separation depending on the flight range (VFR or IFR) of SP class and air traffic service or pilot responsibility. The second level is to avoid collision depending on UAV pilot only.

In this situation „Sense and Avoid" system should fulfill both the function of ensuring separation and avoiding air crash as well. The main requirement connected with crash hazard is defining the safety called "equivalent level of safety" (ELOS). "Equivalent" means correspondent to air crew aviation. This definition allows to fulfill the requirements regarding safety by various $\mathrm{S}$ \&A system users and makes possible the comparison of suggested technical solutions. Initially EUROCONTROL determines ELOS quantitatively as probability of air collision occurrence as high as 0,5 per million flight hours. 
In technical sense, there two types of S\&A system solutions are provided for: the solution with ensuring of UAV continuous communication with manned SP or equipment of UAV in sub-assemblies ensuring crash avoiding. The first solution seems to be more useful but the air traffic services will accept this solution only when the equipment according to the rules will be found on SP boards. However, as there are no regulations, this solution cannot be taken into account in the nearest future. For this reason, it is necessary to undertake works regarding the regulations rules and UAV equipment as well. Works within this domain are conducted by Standard Work Teams (EUROCAE WG73 in Europe and RTCA S.C. 203 in USA). It is currently assumed that UAV should reach the status ensuring their usage in the years 2013-2015.

To solve the problems connected with air traffic safety, the European Defense Agency EDA| has put to life MIDair Collision Avoidance System (MIDCAS) [5] project with the purpose of solving air traffic problems connected with UAV operation in all air space classes of the same degree of access as for crew SP. MIDCAS studies within the field of safety will include „Sense \& Separate” issues because in not-controlled air space one cannot ensure safety in any other way.

\section{Avionic equipment development trends}

The most important priority of air traffic safety causes the necessity to describe safety aims, reliability of hazards and failure conditions, admissible levels of air traffic safety and introduction of strategy to eliminate excessive hazards. Requirements in this field are connected with people working in aviation, using the accepted procedures of airworthy aircrafts (including their on board equipment) and the environment in which the aviation operations are performed.

Board equipment integration, in particular of avionics [9] is conducted with consideration of possibility of situation awareness improvement, decreasing the work load of the crew and simplification of training and air flight performance procedures, especially in the space of big air traffic intensity. Adoption of such priorities can enable quicker decision making process by the crew and appropriate reaction to the hazards occurring during the flight. Usage of integrated avionics (glass cockpit) in newly developed avionic structures is an accomplished fact and A-380 as well as B-787 Dreamliner may serve as an example here. Avionic developed digital systems are not only able to ensure required information level for the crew but their integration with ground systems causes not only the improvement of air 
traffic safety but possibility of further improvement of aircraft usage effectiveness as well.

Development works carried out currently aim at using pilot's language and movements of his head to control SP and at the development of possibility of flights performance in automatic system, including also long lasting flights with limited number of crew members. Collision avoiding systems have improved air traffic safety but making a decision on big aircrafts equipment with self-protection systems did not find not only explicit support but their technical level in great part does not correspond to the hazards, especially in terrorist hazard zones. It is possible that in this field the solutions from programs mentioned in item 2 can be used.

\section{Integration of airport protection systems}

Successful protection of aviation airport infrastructure [3] is now one of the main challenges for safety in general understanding and air traffic safety as well, especially in terrorist hazard regions threatened terroristically. Airport's critical infrastructure should be be characterized by security not only from attack but it should be also safe, with safety understood as normal functionality. Technical development makes possible effective critical infrastructure protection with the aid of more and more technically advanced and more and more sensitive protection systems. For this reason and because of extensiveness of the protected object there a system method is used, making possible complex supervision of airports, ensuring this way air traffic safety. Airport rescue service, that is, mainly, airport fire brigade is directly responsible for carrying out security works, protection of airport infrastructure and training of airport services. [4]. Key technologies for security systems are the priorities in EU Framework Programs and also in technology priorities of European Defense Agency (EDA) in accordance with [6]. Using new technologies should make possible:

- improvement of the level of knowledge about hazards (situational awareness SA);

- protection against using biological, chemical, radioactive and high energy substances

- improvement of critical management processes;

- interoperation and integration of information systems and communication.

Difficulty of protection and monitoring of airport including air traffic hazards consists in : 
- complexity, extensiveness, infrastructure diversity;

- troublesomeness in the range of extensive outside area and sensitive inside objects;

- big accumulation of sensitive objects (aircrafts, fuel storehouses....;

- development of permanent destructions difficult to remove and eliminating the airport from air traffic;

- media attention connected with the airport.

Integration in this situation must take into account the elimination of information excess by subsystems hierarchization, sensors and detectors, possibility of creating local security center, possibility of expansion in additional elements including also communication and observation integrated systems.

\section{Diagnostic testing of airport surface}

The airport surface as any other technical "device" is subject to permanent degradation process. Life of a properly made surface depends above all on material out of which it was made, aircraft types that operate on it, number of air operations and natural environment [2]. It has to be admitted that degradation of airfield surfaces can be accelerated mainly due to the introduction of new, big SP's of A-380, B-757 type. Degradation process is normally slow, stable, although its violent acceleration is possible, bringing about air traffic hazard. For this reason, permanent supervision over technical condition of the surface is conducted by observation and performance of routine diagnostic tests. Evaluation of the technical condition can be obtained in turn, by inventory of surface damages and by technical examination of: coarseness, smoothness, load capacity and other examinations with using ultrasounds and radar technique.

In the case of old airfields or those that do not have up-to-date design documentation there are made: inventory stencils with marking the division into concrete plates, bore-holes in the surface and examination of materials received from the bore-holes. The number of bore-holes should be sufficient for exact structure identification. The bore-holes should be made for different EFL parts (airfield functional element) because during its life it could have been repaired and rebuilt many times. Examinations of this type are often complemented with ground-penetrating radar research.

Examination of surface smoothness [2] consists in moving the pantograph along the tested section of airfield surface and in computer recording of the size of the gap between the pantograph and the surface. The evaluation boils down to the assesment of 5-meter elements corresponding with the concrete 
plates made. On the basis of the measurements there unevenness profiles are made, which, in turn are compared / evaluated on the basis of with previously established criteria.

Surface load-bearing examination [7] is of basic importance for air traffic safety and consists in determination of PCN coefficient (Pavement Classification Number). PCN number is equivalent to $1 / 500$ of permissible load (in $\mathrm{kg}$ ) applied to the surface through one wheel of 1,25 MPa pressure. During estimating of the surface load-bearing, its PCN coefficient is compared with the ACN (Aircraft Classification Number) coefficient which each SP possesses.. An example of ACN for the B767-300ER aircrafts given in Table 2.

Table 2

\begin{tabular}{|l|c|c|c|c|c|c|c|c|c|}
\hline \multirow{2}{*}{ Aircraft } & Mass & \multicolumn{4}{|c|}{ Stiff surfaces } & \multicolumn{4}{|c|}{ Elastic surfaces } \\
\cline { 3 - 10 } & {$[\mathrm{kg}]$} & A & B & C & D & A & B & C & D \\
\hline Boeing & 178 & & & & & & & & \\
B767- & 400 & 48 & 57 & 68 & 78 & 53 & 59 & 72 & 94 \\
300ER & & & & & & & & & \\
\hline
\end{tabular}

Surface load-bearing is examined with airfield deflectometer e.g. of HWD (Heavy Weight Deflectometr) type. The map of separate airfield elements, developed on the basis of the examinations, enables detection of weak places in the structure. It is obvious that for the airfield surface, the deflectometer should simulate the load of the computational aircraft (C130 Hercules - 160-180 kN - depending on type). In the case of necessity of receiving on the airfield a given SP type, the procedure of load-bearing designation is "reversed" and for the assumed PCN coefficient the permissible number of air operations is calculated. The data obtained form the basis for repair work planning (range) as well as term of their commencement (with the assumed air traffic intensity).

ICAO Aerodromes Annex 14 determines in turn the indexes of coarseness for which it carring out of the air operations in the airfield is possible . For a specified aircraft type (in its instruction manual), coarseness parameters are also determined taking into account water, snow, ice, mad, sand or their lack on the airfield surface. Annex 14 provides for two coarseness coefficients: coarseness value (tacking) at which the operations should be stopped and corrective - servicing actions should be performed and the minimal value of coarseness, at which the crew must receive information that the airstrip can be slippery. In the case of air force, the average coefficient of coarseness should not be below 0,5 and (for example) instruction manual for Jak-40 aircraft permits carrying out operations at minimal coefficient of 0,3 . 
Diagnostic tests performed allow to determine the technical condition of airfield surfaces and, at the same time, specify hazards for the air traffic safety. In simple cases (e.g. insufficient load-bearing), it is enough to correct the aircraft traffic on taxi tracks and, in more complicated cases (damage of operational aircrafts), it is necessary to take more radical decisions (repair).

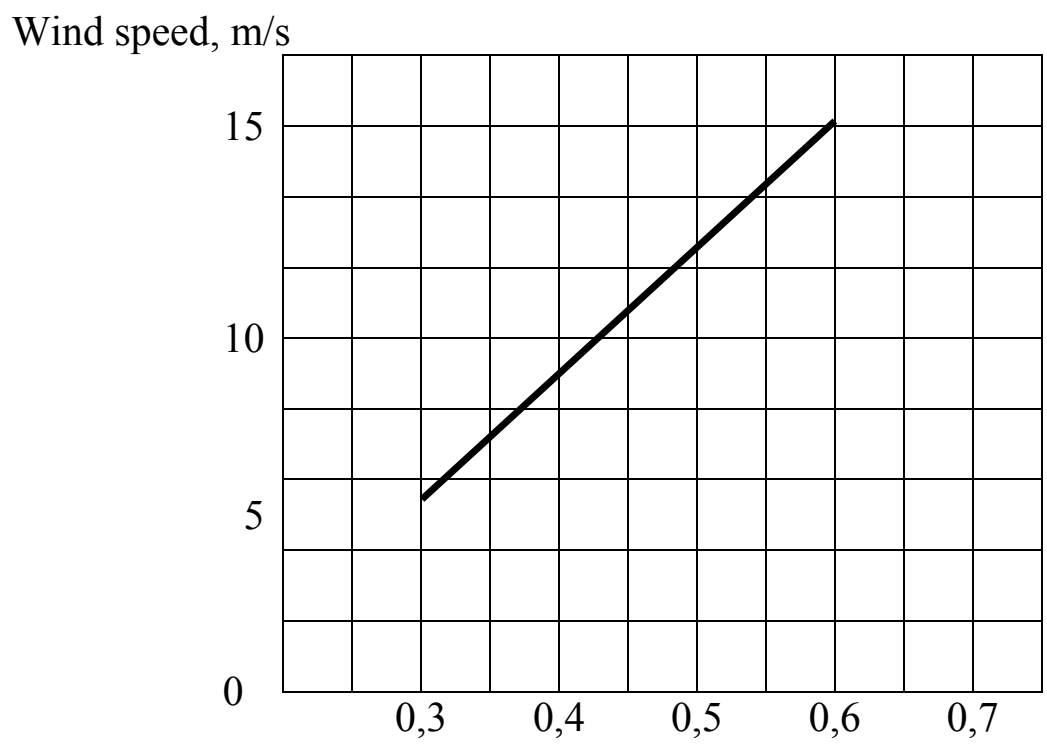

Airstrip coarseness coefficient, $\mu$

Fig. 1. Permitted side wind speed at taking off and landing vs. airstrip grip coefficient

\section{Summary}

The condition of air traffic safety in Polish aviation requires not only undertaking current prophylactic activities but introduction of technical and organizational solutions on a large scale as well. Such a proposal of improvement is the ZEUS program (Integrated transport safety system) realization of which, undertaken in 2006, should make preventing dangerous aviation crashes possible, enabling prevention of their effects, hazard analyses and successful prevention. The direct aim of the program is the development of the conception of supporting decision processes of the new aviation safety management system, making the transfer to designing system of computer support possible.

Similar activities but on a much larger scale are undertaken within EU, and the "Air Traffic Uniform Management System" SESAR initiated within 
„European Transport in FP7” should enable the development of air transport infrastructure including satellite navigation (GALILLEO program), gaining interoperationality - creating the Uniform European Airspace and development of new technologies making the increase in air transport effectiveness possible. As a result of the program realization, the new integrated system of air traffic management should ensure tenfold improvement of safety indexes with simultaneous threefold increasing of the air traffic capacity.

\section{Bibliography}

1. Contract 05-R \& T-003. Technology Demonstration Study on Sense \& Avoid Technologies for Long Endurance Unmanned Air Vehicles.

2. Grabowski P. „Diagnostyka nawierzchni lotniskowych”. „Lotnisko” no 4 Warsaw, 2007

3. Loroch L., Mądrzycki P., Świech M., „Zintegrowany system ochrony lotniska. Aspekty techniczne" RAST 2007. June 14-16. Istambul Turkey, 2007

4. Lotniskowa Straż Pożarna „Technologie dla bezpieczeństwa ruchu lotniczego - wdrażanie przez służby ratownicze nowych technologii na rzecz poprawy bezpieczeństwa ruchu lotniczego". I Konferencja „Lotnisko - 2008” 13-14.02.2008. Warsaw, 2008

5. MIDair Collision Avoidance System (MIDCAS) for UAV Systems "Traffic Insertion Sense \& Avoid" - EDA meeting.

6. Mierczyk Z. Systemy monitorowania zagrożeń bezpieczeństwa. Wojskowa Akademia Techniczna (Military University of Technology), Warsaw, 2007

7. Nita P. „Betonowe nawierzchnie lotniskowe”. Wydawnictwo Instytutu Technicznego Wojsk Lotniczych. Warsaw, 2005

8. Sławiński M. „Bezpieczeństwo żeglugi powietrznej w polskiej przestrzeni powietrznej”. I Konferencja „Lotnisko - 2008” 1314.02.2008. Warsaw, 2008

9. Żyluk A. „Technologie dla bezpieczeństwa ruchu lotniczego” I Konferencja „Lotnisko - 2008” 13-14.02.2008. Warsaw, 2008 


\section{NOWE TECHNOLOGIE DLA BEZPIECZEŃSTWA RUCHU LOTNICZEGO}

\section{Wstęp}

Duże natężenie ruchu lotniczego w wymiarze globalnym dotyczy szczególnie rejonów Ameryki Północnej, Azji Południowo-Wschodniej oraz Europy. Położenie Polski w Europie Centralnej powoduje, że przewidywany wzrost cywilnego ruchu lotniczego w krajach Europy środkowej będzie w najbliższych latach na poziomie $15-16 \%$ [8] a przy obecnym wzroście w Polsce na poziomie 20\%. Utrzymanie współczynnika wypadkowości (ilość wypadków na milion odprawionych pasażerów). Na dotychczasowym poziomie jest działaniem niedostatecznym, ale tendencja zmniejszania współczynnika wypadkowości nie jest zagwarantowana. Mierzona w ten sposób skuteczność procesów bezpieczeństwa ma, co prawda tendencję spadkowa, ale w latach 1992-2006 nie osiągnięto znacznych postępów, a ilość ofiar śmiertelnych wskutek wypadków lotniczych w Europie jest proporcjonalna do ruchu lotniczego. Wpływ na taki stan rzeczy może mieć: duże natężenie ruchu lotniczego, system zarządzania ruchem lotniczym nie odpowiadający w części natężeniu ruchu lotniczego, ostra konkurencja na rynku usług lotniczych prowadząca do nadmiernej eksploatacji sprzętu, problemy szkoleniowe szczególnie ważne dla załóg statków powietrznych. Pozytywnym faktem w tym zakresie może być wprowadzanie nowych typów statków powietrznych z wysokim poziomem bezpieczeństwa lotu (ruchu lotniczego) uzyskanego na bazie wykorzystania najnowszych technologii. Formułowane wymagania dla systemu zarządzania ruchem lotniczym (ATM) przewiduje, że do 2015 roku ilość wypadków z powodu błędów w zarządzaniu powinny się zmniejszyć o ok. $2 / 3$. Oznacza to konieczność opracowania i wdrożenia nowego systemu zarządzania ruchem lotniczym.

Wsparciem technicznym w zakresie bezpieczeństwa ruchu lotniczego moga być nowe technologie wykorzystywane na pokładach liniowych pasażerskich statków powietrznych, ale i technologie opracowywane dla lotnictwa ogólnego (general aviation (GA)) oraz lotnictwa wojskowego operującego w dużej części z cywilnych portów lotniczych.

Zestawienie zdarzeń lotniczych w polskim lotnictwie cywilnym do 31.12.2006r. przedstawia tabela 1 . Na pogorszenie bezpieczeństwa ruchu 
lotniczego w 2006 roku istotny wpływ miało niedoszkolenie pilotów samolotów prywatnych, w tym głównie ultralightów, pogorszenie poziomu obsługi technicznej, a w lotnictwie komunikacyjnym wzrost niebezpiecznych zbliżeń między samolotami.

Tabela 1

\begin{tabular}{|c|c|c|c|c|c|}
\hline \multirow{2}{*}{ Rok } & \multirow{2}{*}{$\begin{array}{c}\text { Liczba } \\
\text { zdarzeń }\end{array}$} & \multicolumn{4}{|c|}{ w tym } \\
\cline { 3 - 6 } & & wypadki & $\begin{array}{c}\text { wypadki } \\
\text { śmiertelne }\end{array}$ & $\begin{array}{c}\text { poważne } \\
\text { incydenty }\end{array}$ & incydenty \\
\hline 2006 & 378 & 100 & 16 & 16 & 268 \\
\hline 2005 & 297 & 75 & 10 & 37 & 185 \\
\hline 2004 & 314 & 98 & 16 & 15 & 201 \\
\hline 2003 & 203 & 97 & 14 & 2 & 108 \\
\hline
\end{tabular}

W ostatnich latach istotne stały się technologie zapewniające skuteczną ochronę infrastruktury lotniskowej szczególnie narażonej na ataki terrorystyczne. Kluczowe technologie dla systemów bezpieczeństwa mieszczą się w priorytetach Unii Europejskiej.

\section{Bezpilotowe statki powietrzne, a bezpieczeństwo ruchu lotniczego.}

Użytkowanie bezpilotowych statków powietrznych (BSP) w otwartej przestrzeni powietrznej powoduje, że konieczne jest rozwiązanie wielu problemów i zagadnień, które umożliwią operacyjne użytkowanie BSP a tym samym dalszy ich rozwój. Problemy te zdefiniowane przez JAA i EUROCONTROL, znalazły swoje miejsce $w$ pracy studyjnej zorganizowanej przez Europejską Agencję Obrony pn. „Technology Demonstration Study on Sense Avoid Technologies for Long Endurance Unmaned Air Vehicles" [1]. Celem studium było zdefiniowanie rozwiązań technicznych w zakresie technologii „Sense and Avoid” dla BSP w celu zintegrowania ich $\mathrm{z}$ cywilnym ruchem lotniczym i umożliwienie ich wykorzystania w operacjach zarządzania kryzysowego.

Unikanie kolizji jest określone na dwóch poziomach: pierwszy to zapewnienie separacji, w zależności od zakresu lotu (VFR lub IFR), klasy SP i odpowiedzialności służby ruchu lotniczego lub pilota. Drugi poziom to unikanie kolizji zależne tylko od pilota BSP. W tej sytuacji system „Sense and Avoid" powinien pełnić funkcję zarówno zapewnienia separacji jak i unikania kolizji w locie. Głównym wymaganiem związanym z ryzykiem kolizji jest zdefiniowanie bezpieczeństwa, nazywanego „równorzędnym poziomem bezpieczeństwa" (ELOS - Equivalent Level of Safety). 
„Równorzędnym” oznacza odpowiadający lotnictwu załogowemu. Definicja ta pozwala na spełnianie wymagań $\mathrm{w}$ zakresie bezpieczeństwa przez różnych użytkowników systemu $\mathrm{S} \& \mathrm{~A}$ i umożliwia porównanie proponowanych rozwiązań technicznych. Wstępnie EUROCONTROL określa ilościowo ELOS jako prawdopodo-bieństwo wystąpienia kolizji w powietrzu wynoszące 0,5 na milion godzin lotu.

W sensie technicznym przewiduje się dwa typy rozwiązań systemu S\&A: rozwiązanie z zapewnieniem ciagłej łączności UAV z załogowym SP lub wyposażenie UAV w podzespoły zapewniające unikanie kolizji. Pierwsze rozwiązanie wydaje się być bardziej korzystne, jednak służby ruchu lotniczego zaakceptują to rozwiązanie tylko wtedy, gdy na pokładach SP znajdzie się wyposażenie zgodne z przepisami. Ponieważ jednak przepisów brak, więc rozwiązanie to nie może być brane pod uwagę w najbliższym czasie. $\mathrm{Z}$ uwagi na to konieczne jest podjęcie prac zarówno $\mathrm{w}$ zakresie przepisów jak i wyposażenia UAV. Prace w tym zakresie prowadzone sa przez Standaryzacyjne Grupy Robocze (EUROCAE WG73 w Europie i RTCA S.C. 203 w USA). Obecnie przyjmuje się, że UAV powinny osiagnąć w latach 2013-2015 status zapewniający ich użytkowanie.

Dla rozwiązania problemów związanych $\mathrm{z}$ bezpieczeństwem $\mathrm{w}$ ruchu lotniczym Europejska Agencja Obrony EDA uruchomiła projekt MIDair Collision Avoidance System (MIDCAS) [5], którego celem jest rozwiązanie problemów ruchu lotniczego przy operowaniu UAV we wszystkich klasach przestrzeni powietrznej z tym samym stopniem dostępu jaki mają załogowe SP. Studia MIDCAS w zakresie bezpieczeństwa będą zawierać zagadnienia „Sense \& Separate” ponieważ w niekontrolowanej przestrzeni powietrznej nie można w inny sposób zapewnić bezpieczeństwa.

\section{Kierunki rozwoju wyposażenia awionicznego}

Najwyższy priorytet bezpieczeństwa ruchu lotniczego powoduje konieczność określania celów bezpieczeństwa, wiarygodności zagrożeń i stanów awaryjnych, dopuszczalnych poziomów bezpieczeństwa ruchu lotniczego oraz wprowadzanie strategii eliminującej nadmierne zagrożenia. Wymagania $w$ tym zakresie dotyczą ludzi pracujących w lotnictwie, stosowania przyjętych procedur zdatności statków powietrznych (w tym ich wyposażenia pokładowego) oraz środowiska w jakim wykonywane sa operacje lotnicze.

Integracja wyposażenia pokładowego, w tym głównie awioniki [9] prowadzona jest $\mathrm{z}$ uwzględnieniem możliwości poprawy świadomości sytuacyjnej, zmniejszanie obciążenia pracą załogi oraz uproszczenia 
szkolenia i procedur wykonywania lotów, szczególnie w przestrzeni o dużym natężeniu ruchu lotniczego. Przyjęcie takich priorytetów umożliwić może szybsze podejmowanie decyzji przez załogę oraz adekwatne reagowanie do zaistniałych w czasie lotu zagrożeń. Wykorzystywanie zintegrowanej awioniki (glass cockpit) w nowoopracowanych konstrukcjach lotniczych jest faktem dokonanym, a przykładem może być zarówno A-380 jak i B-787 Dreamliner. Rozbudowane awioniczne systemy cyfrowe są nie tylko w stanie zapewnić wymagany poziom informacji załodze, ale ich integracja z systemami naziemnymi powoduje nie tylko poprawę bezpieczeństwa ruchu lotniczego, ale i możliwość dalszej poprawy efektywności wykorzystania statków powietrznych.

Prowadzone obecnie prace rozwojowe zmierzają wykorzystania mowy oraz ruchów głowy pilota do sterowania SP oraz rozwoju możliwości wykonywania lotów w systemie automatycznym, w tym również w długotrwałych lotach przy ograniczonym składzie załogi. Systemy unikania kolizji poprawiły bezpieczeństwo ruchu lotniczego, ale podjęcie decyzji o wyposażeniu dużych statków powietrznych w systemy samoobrony (self protection) nie znalazły nie tylko jednoznacznego wsparcia, ale ich poziom techniczny w dużej czesści nie odpowiada zagrożeniom, szczególnie w strefach zagrożeń terrorystycznych. Być może zastosowanie $\mathrm{w}$ tym zakresie znajdą rozwiązania $\mathrm{z}$ programów zasygnalizowanych w p. 2.

\section{Integracja systemów ochrony lotnisk}

Skuteczna ochrona lotniczej infrastruktury lotniskowej [3] jest obecnie jednym z głównych wyzwań dla ogólnie rozumianego bezpieczeństwa jak i bezpieczeństwa ruchu lotniczego szczególnie w rejonie zagrożonym terrorystycznie. Infrastruktura krytyczna lotniska powinna być zabezpieczona nie tylko od ataku (security), ale także powinna być bezpieczna (safety) rozumianego jako normalne funkcjonowanie. Postęp technologiczny umożliwia skuteczną ochronę infrastruktury krytycznej z pomoca coraz bardziej zaawansowanych technicznie i coraz bardziej czułych systemów ochrony. $\mathrm{Z}$ tego powodu oraz $\mathrm{z}$ powodu rozległości ochranianego obiektu stosuje się systemowe podejście umożliwiające kompleksowy nadzór nad portami lotniczymi, zapewniając $\mathrm{w}$ ten sposób bezpieczeństwo ruchu lotniczego. Bezpośrednio za prowadzenie działań ratowniczych, zabezpieczenie infrastruktury lotniskowej oraz szkolenie służb lotniskowych odpowiada służba ratownictwa portu, a tym samym 
głównie lotniskowa straż pożarna [4]. Kluczowe technologie dla systemów bezpieczeństwa są priorytetami w Programach Ramowych UE, a także $\mathrm{w}$ priorytetach technologicznych Europejskiej Agencji Obrony (EDA) zgodnie z [6]. Wykorzystanie nowych technologii powinno umożliwić:

- poprawienie poziomu wiedzy o zagrożeniach (situational awareness SA);

- ochronę przed użyciem substancji biologicznych, chemicznych, radioaktywnych oraz wysokoenergetycznych;

- usprawnienie procesów zarządzania kryzysowego;

- interoperacyjność i integrację systemów informacyjnych i łączności.

Trudność ochrony i monitorowanie zagrożeń portów lotniczych, a w tym i ruchu lotniczego, polega na:

- złożoności, rozległości, zróżnicowaniu infrastruktury;

- kłopotliwości pod względem ochrony rozległej strefy zewnętrznej oraz wrażliwych obiektów wewnętrznych;

- dużej kumulacji obiektów wrażliwych (statki powietrzne, składy paliwa...);

- powstawaniu trwałych zniszczeń trudnych do usunięcia eliminujących lotnisko z ruchu lotniczego;

- medialności lotniska.

Integracja $\mathrm{w}$ takiej sytuacji musi uwzględniać wyeliminowanie nadmiaru informacji przez hierarchizację podsystemów, sensorów i detektorów, możliwość tworzenia lokalnego ośrodka ochrony, możliwość rozbudowy o kolejne elementy, a w tym również zintegrowane systemy łączności oraz systemy obserwacji.

\section{Diagnostyka nawierzchni lotniskowej}

Nawierzchnia lotniskowa, podobnie jak inne „urządzenie” techniczne podlega ciagłemu procesowi degradacji. Żywotność prawidłowo wykonanej nawierzchni zależy przede wszystkim od materiału z jakiego została wykonana, typów samolotów jakie na niej operuja, ilości operacji lotniczych oraz oddziaływania środowiska naturalnego [2]. Przyznać trzeba, że degradacja nawierzchni lotniskowych może ulec przyspieszeniu głównie z uwagi na wprowadzenie nowych, dużych SP, typu A-380, B-757. Proces degradacji jest zazwyczaj powolny, stabilny, jednak możliwe jest jego gwałtowne przyspieszenie, mogące zagrozić bezpieczeństwu ruchu lotniczego. $\mathrm{Z}$ tego powodu prowadzi się ciaggly nadzór nad stanem technicznym nawierzchni poprzez obserwację oraz prowadzenie 
okresowych badań diagnostycznych. Ocenę stanu technicznego można uzyskać z kolei przy pomocy inwentaryzacji uszkodzeń nawierzchni oraz przez badanie techniczne: szorstkości, równości, nośności, innych badań z wykorzystaniem ultradźwięków oraz techniki radarowej.

W stosunku do lotnisk starych bądź nie posiadających aktualnej dokumentacji projektowej wykonuje się: szablony inwentaryzacyjne, z zaznaczeniem podziału na płyty betonowe, odwierty w nawierzchni i bada materiały uzyskane $\mathrm{z}$ odwiertów. Ilość odwiertów powinna być wystarczająca dla dokładnej identyfikacji konstrukcji. Odwierty wykonać należy dla różnych części EFL (element funkcjonalny lotniska) ponieważ w ciagu swego życia mógł on być wielokrotnie remontowany i przebudowywany. Badania tego typu często uzupełnia się badaniami przy pomocy penetroradaru.

Badanie równości nawierzchni [2] polega na przejechaniu pantografem wzdłuż badanego odcinka nawierzchni lotniskowej i zarejestrowaniu na komputerze wielkości prześwitu pomiędzy pantografem, a nawierzchnią. Ocena sprowadza się do oceny odcinków 5-metrowych odpowiadających wykonanym płytom betonowym. Na podstawie pomiarów wykonuje się profile nierówności, które następnie porównuje się /ocenia za podstawie ustalonych wcześniej kryteriów.

Badanie nośności nawierzchni [7] ma podstawowe znaczenie dla bezpieczeństwa ruchu lotniczego i polega na wyznaczaniu wskaźnika PCN (Pavement Classification Number). Liczba PCN jest równoważna 1/500 dopuszczalnego obciążenia ( $\mathrm{w} \mathrm{kg}$ ) przyłożonego do nawierzchni za pośrednictwem pojedynczego koła z ciśnieniem 1,25 MPa.

Oceniając nośność nawierzchni porównuje się jej wskaźnik PCN z posiadanym przez każdy SP wskaźnikiem ACN (Aircraft Classification Number). Przykład ACN dla samolotu B767-300ER podano w tabeli 2.

Tabela 2

\begin{tabular}{|l|c|c|c|c|c|c|c|c|c|}
\hline \multirow{2}{*}{ Samolot } & Masa & \multicolumn{4}{|c|}{ Nawierzchnie sztywne } & \multicolumn{4}{|c|}{ Nawierzchnie podatne } \\
\cline { 3 - 10 } & {$[\mathrm{kg}]$} & $\mathrm{A}$ & $\mathrm{B}$ & $\mathrm{C}$ & $\mathrm{D}$ & $\mathrm{A}$ & $\mathrm{B}$ & $\mathrm{C}$ & $\mathrm{D}$ \\
\hline Boeing & 178 & 48 & 57 & 68 & 78 & 53 & 59 & 72 & 94 \\
B767- & 400 & 48 & 57 & & & & & & \\
300ER & & & & &
\end{tabular}

Nośność nawierzchni badana jest przy pomocy ugięciomierza lotniskowego np. typu HWD (Heavy Weight Deflectometr). Wykonana na podstawie badań mapa poszczególnych elementów lotniska umożliwia wykrycie słabych miejsc w konstrukcji. Jest oczywiste, że dla nawierzchni 
lotniskowej ugięciomierz powinien symulować obciążenie samolotu obliczeniowego (C-130 Hercules - 160-180 kN - w zależności od typu). W przypadku konieczności przyjmowania na lotnisku określonego typu SP, procedura oznaczenia nośności jest „odwracana” i dla założonego wskaźnika PCN oblicza się dopuszczalną liczbę operacji lotniczych. Uzyskane dane są podstawą planowania prac remontowych (zakresu) oraz terminu ich podjęcia (przy założonym natężeniu ruchu lotniczego).

ICAO Aerodromes Aneks 14 określa z kolei wskaźniki szorstkości dla których możliwe jest prowadzenie na lotnisku operacji lotniczych. Dla określonego typu statku powietrznego (w jego instrukcji użytkowania) również określa się wskaźniki szorstkości, przy uwzględnieniu na nawierzchni lotniskowej: wody, śniegu, lodu, błota, piasku lub ich braku. Aneks 14 przewiduje dwa wskaźniki szorstkości: wartość szorstkości (sczepności), przy której należy wstrzymać operacje i przeprowadzić działania korygujące - obsługowe oraz minimalną wartość szorstkości, przy której należy podać informację załogom, że droga startowa może być śliska. W przypadku lotnictwa wojskowego średni współczynnik szorstkości nie powinien być mniejszy niż 0,5 , a (dla przykładu) instrukcja samolotu Jak-40 dopuszcza prowadzenie operacji przy minimalnym współczynniku 0,3.

Prędkość wiatru, m/s

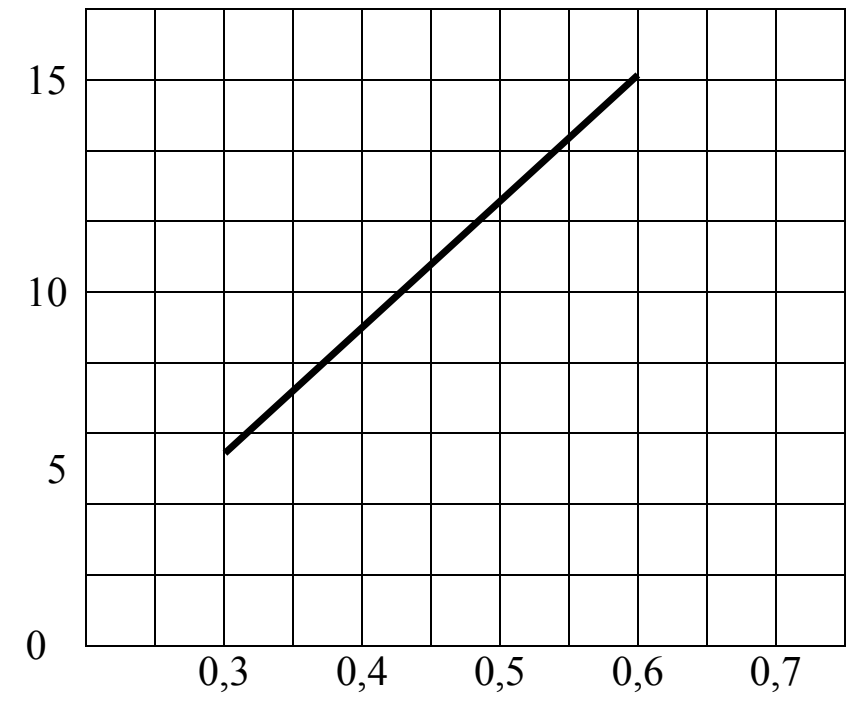

Współczynnik szorstkości drogi startowej, $\mu$

Rys. 1. Zależność dopuszczalnej prędkości wiatru bocznego przy starcie i lądowaniuod wspótczynnika przyczepności drogi startowej 
Prowadzone badania diagnostyczne pozwalają określić stan techniczny nawierzchni lotniskowych, a tym samym określić zagrożenia dla bezpieczeństwa ruchu lotniczego. W przypadkach prostych (np. niedostatecznej nośności) wystarczy korekta ruchu samolotów na drogach kołowania, w przypadkach bardziej złożonych (uszkodzenia operujących samolotów) niezbędne jest podjęcie decyzji bardziej radykalnych (remont).

\section{Podsumowanie}

Stan bezpieczeństwa ruchu lotniczego $\mathrm{w}$ polskim lotnictwie wymaga nie tylko podejmowania bieżących działań profilaktycznych, ale wprowadzenia rozwiązań technicznych i organizacyjnych na dużą skalę. Taką propozycją poprawy jest program ZEUS (Zintegrowany system bezpieczeństwa transportu), którego realizacja podjęta w 2006r., umożliwić powinna zapobieganie niebezpiecznym wypadkom lotniczym, zapobieganie ich skutkom, analizowanie zagrożeń oraz skuteczną profilaktykę.Bezpośrednim celem programu jest opracowanie koncepcji wspomagania procesów decyzyjnych nowego systemu zarządzania bezpieczeństwem w lotnictwie umożliwiającej przejście do projektowania systemu wsparcia informatycznego.

Podobne działania, ale $\mathrm{w}$ znacznie większej skali, podejmowane są w ramach UE, a „Jednolity System Zarządzania Ruchem Lotniczym” SESAR uruchomiony w ramach „European Transport in FP7” umożliwić powinien rozwój infrastruktury transportu lotniczego, w tym nawigacji satelitarnej (program GALILLEO), uzyskanie interoperacyjności stworzenie Jednolitej Europejskiej Przestrzeni Powietrznej, oraz opracowanie nowych technologii umożliwiających zwiększenie efektywności transportu lotniczego. W wyniku realizacji programu nowy zintegrowany system zarządzania ruchem lotniczym zapewnić powinien dziesięciokrotną poprawę wskaźników bezpieczeństwa przy trzykrotnym zwiększeniu przepustowości w ruchu lotniczym.

\section{Literatura}

1. Contract 05-R \& T-003. Technology Demonstration Study on Sense \& Avoid Technologies for Long Endurance Unmanned Air Vehicles.

2. Grabowski P. „Diagnostyka nawierzchni lotniskowych”. „Lotnisko” nr 4. Warszawa, $2007 \mathrm{r}$. 
3. Loroch L., Mądrzycki P., Świech M., „Zintegrowany system ochrony lotniska. Aspekty techniczne”. RAST 2007. June 14-16. Istambul Turkey, $2007 \mathrm{r}$.

4. Lotniskowa Straż Pożarna „Technologie dla bezpieczeństwa ruchu lotniczego - wdrażanie przez służby ratownicze nowych technologii na rzecz poprawy bezpieczeństwa ruchu lotniczego". I Konferencja „Lotnisko - 2008” 13-14.02.2008. Warszawa, 2008 r.

5. MIDair Collision Avoidance System (MIDCAS) for UAV Systems „Traffic Insertion Sense \& Avoid” - EDA meeting.

6. Mierczyk Z. Systemy monitorowania zagrożeń bezpieczeństwa. Wojskowa Akademia Techniczna, Warszawa, 2007 r.

7. Nita P. „Betonowe nawierzchnie lotniskowe”. Wydawnictwo Instytutu Technicznego Wojsk Lotniczych. Warszawa, 2005 r.

8. Sławiński M. „Bezpieczeństwo żeglugi powietrznej w polskiej przestrzeni powietrznej”. I Konferencja „Lotnisko - 2008” 1314.02.2008. Warszawa, $2008 \mathrm{r}$.

9. Żyluk A. „Technologie dla bezpieczeństwa ruchu lotniczego” I Konferencja „Lotnisko - 2008” 13-14.02.2008. Warszawa, 2008 r.

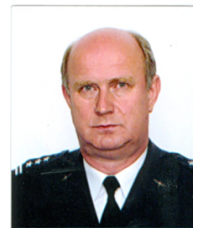

Ph.D., Eng., LOROCH Leszek, AFIT, R\&D coordinator of aeronautical projects. Specialist in the field of aircraft armament. Experienced in designing, testing, and implementation of modernized on-board aircraft armament and air combat assets. Former member of the commission for aircraft accidents investigation. A lot of publications in the field.

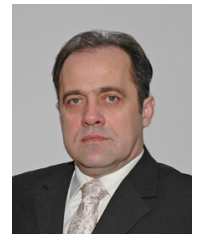

Andrzej Żyluk, PhD Eng., a vice-director of ITWL (Air Force Institute of Technology) for $R \& D$, an expert in the air armament systems. He Has employed himself in developing the air traffic safety systems. Author of tens of scientific and engineering studies, also reports on testing work. 